\title{
Krátká věčnost. Narativní inscenace věčnosti do roku 1800 \\ Kateřina Smyčková
}

DOI: 10.21104/CL.2021.1.03

Short Eternity. Narrative Representations of Eternity to 1800

\begin{abstract}
This study follows on from previous research on the "ancien time régime" (to around 1800) by R. Koselleck and A. Assmann. It examines representations of eternity in exempla, legends and other texts. The basic motif of these texts is the break with the time, i.e. the situation where the mortal man enters a different time regime (such as paradise) and spents there a seemingly a short time, while, in fact, hundreds of years have passed. The study describes the basic types of these tales (song of the bird, wedding, vision, etc.) and analyses their common motifs.
\end{abstract}

\section{Key words}

time, eternity, literature, exemplum

\section{Acknowledgment}

Studie vznikla v rámci IRP projektu Ostravské univerzity „Identita míst a regionů - výzkum rukopisných kancionálů a poutnické literatury 17. a 18. století (reg. č. 201827)“.

\section{Contact}

Mgr. Kateřina Smyčková, Ph.D., Filozofická fakulta Ostravské univerzity, Reální 5, 70103 Ostrava, Czech Republic; e-mail: katerina.smyckova@) seznam.cz

\section{Jak citovat / How to cite}

Smyčková, Kateřina. 2021. Krátká věčnost. Narativní inscenace věčnosti do roku 1800. Českýlid 108, 51-66. https://doi.org/10.21104/CL.2021.1.03 


\section{Starý a moderní režim časovosti}

Žalmista praví, že tisíc let je u Boha jako včerejší den, který minul, jako jedna noční hlídka (Ž 90,4). Poukazuje tak na jeden ze základních rozporů mezi Stvořitelem a stvořením: nekonečnost a konečnost bytí, věčné trvání a ukotvení do času. Věčnost je Božím atributem, člověk náleží času. Podle sv. Augustina je čas charakterizován proměnlivostí, stárnutím a smrtí, nostalgií a temnotou; věčnost především neměnností, plností, usebráním, bytím u sebe doma a světlem (Ricoeur 2000: 52). Přestože středověcí i raně novověcí teologové přiznávali, že věčnost nelze popsat pomocí časových jednotek, můžeme se např́klad v pojednáních o odpustcích setkat s pokusy přepočítat čas pozemských odpustků na dobu, kterou musí duše strávit v očistci (Gurevič 1996: 281).

Také metafory, jimiž autoři této doby přibližují věčnost nejširším vrstvám obyvatel, přejímají metody lidského počítání času: vybízejí čtenáře či posluchače, aby si představil velký kopec písku, z nějž každý rok odnese anděl jediné zrnko a ubírá tak dlouho, dokud z kopce nic nezbyde; aby si představil hř́ŕńíka, který v pekle vypláče jednu slzu za tisíc let a pláče tak dlouho, dokud z jeho slz nebude větší potopa než za dnů Noe; aby si představil skálu, k níž jednou za tisíc let přiletí ptáček, obrousí si o ni zobák a dělá to tak dlouho, dokud ji zcela neobrousí. Tyto a podobné další obrazy kolovaly jako topoi jak v dobové nábožensky vzdělavatelné literatuře, tak v kázáních či duchovních písních (namátkově viz napr. Manni 1676: bez str. - 4. část; Malobický 1681: 138-139; Šteyer 1683: 987-989). Jejich autoři však obvykle nezapomněli dodat, že i kdyby anděl odnesl všechna zrnka, hříšníkovy slzy naplnily svět či ptáček obrousil skálu, „věčnost bude v celosti, nic jí neubude“" (Šteyer 1683: 988).

Věčnost a její nezměřitelná délka byly tématem, jež nepřestávalo fascinovat všechny společenské vrstvy přinejmenším do konce 18. století. Cílem této studie je ukázat, jakými způsoby byla inscenována v literatuře od raného středověku až přibližně do roku 1800 ; jaké společné atributy nesla v exemplech, pohádkách, viděních atp. Vzhledem k tématu i pramenům se budu opírat především o metodologii literární historie, často se však budu pohybovat též na poli folkloristiky či kulturologie. Není v mých možnostech obsáhnout veškerou sekundární literaturu ani veškeré prameny, jež by mohly být pro tuto práci prínosem; laskavý čtenář necht' tuto studii vnímá spíše jako nástin obsáhlého tématu. Studie představuje souhrn mých dosavadních výzkumů. Jejím účelem není zahltit čtenáře katalogem narativních syžetů, ale spíše se je pokusit typologizovat, nabídnout vybrané př́íklady a jejich interpretaci. Těžištěm mého zájmu jsou české prameny, většina z nich je však svázána s širší, především evropskou kulturní tradicí. Proto 
zde často překračuji rozsah bohemikálního písemnictví a snažím se svůj výklad rozhojnit př́klady z jiných (evropských) literatur.

V tématu, jež zde budu sledovat, hraje důležitou úlohu „vytržení z času“: situace, kdy se člověk ocitne $\mathrm{v}$ jiném časovém režimu, vystoupí z času ostatních smrtelníků a podílí se na časovém režimu věčnosti. Tento „průlom posvátného [...] umožňuje ontologický přechod z jednoho modu bytí do druhého" (Eliade 1994: 46), proto se také hrdinův modus vivendi proměňuje podle řádu věčnosti: nejí, nespí, nestárne. Modus „posvátného času“, jak jej definoval Mircea Eliade, nese shodné rysy s časovým režimem věčnosti, jak se jej pokusím v této studii představit. Eliade upozorňuje, že jej lze dosáhnout nejčastěji prostřednictvím rituálů či svátků, díky čemuž se jedinec vymaňuje z běhu historického času a žije ve „věčné mytické př́tomnosti“ (Eliade 1994: 50).

Rok 1800 kladu jako hrubý mezník, jenž rozděluje starý a moderní režim rozumění a prožívání času, a to po vzoru Reinharta Kosellecka a Aleidy Assmannové. Mnohé prŕklady, jež zde uvádím, ovšem zvolenou hranici překračují - vymezující je spíše starý a moderní způsob vnímání času, přičemž oba tyto způsoby mohly po dlouhou dobu koexistovat. Podle Kosellecka nastala koncem 18. století strukturní změna, společnost začala jinak nahlížet na čas (Koselleck klade tuto změnu do souvislosti s Francouzskou revolucí). Ve „starém režimu časovosti“ žili lidé v permanentním očekávání věčnosti; budoucnost byla totožná s eschatologií a vše, co očekávali, se podobalo jejich zkušenosti s minulostí. Minulost, př́tomnost i budoucnost představovaly stejný časový modus, který nepodléhal změnám: statický čas (Koselleck 1989: 21, 33). Věčnost vstupovala do lidského času prostřednictvím eschatologie - a právě díky permanentnímu eschatologickému povědomí, jež se nevztahovalo pouze $\mathrm{k}$ neurčité budoucnosti, ale ovlivnilo i každodenní přítomnost, stála věčnost lidskému času mnohem blíž než v moderním režimu. Prolamování věčnosti do př́tomnosti bylo mnohem snazší. Kolem roku 1800 přestala být budoucnost očekáváním konce času, ale naopak nového času. Došlo k překročení zkušenostního horizontu, budoucnost se již nepodobala minulosti a př́tomnosti, ale mohla být naplněna jinými obsahy (Koselleck 1989: 27, 33). Koselleckovu koncepci revidovali další badatelé mj. s ohledem na dějiny a kulturu jiných národů, pro něž nebyla Francouzská revoluce natolik zásadní. Nicméně rok 1800 všeobecně uznali jako hrubý předěl mezi starým a novým prožíváním času.

Podstatné doplnění Koselleckovy teze přinesly práce Aleidy Assmannové, v nichž za prvé konstatovala, že tento proces probíhal mnohem pomaleji. Podle této autorky se nový postoj k času etabloval již v 17. století, ale ještě v průběhu 19. století se lze setkat se starým režimem časovosti (Assmann 
2013: 47). Rovněž zavedla pojem kulturního času. Podle Assmannové bylo pro starý režim typické, že vedle sebe probíhaly paralelně různé historie - každá kultura měla svůj vlastní čas. Tyto dějiny probíhaly na pozadí věčnosti, $\mathrm{k}$ jejich protnutí mělo dojít až na posledním soudu; výrazným znakem starého režimu časovosti byla tedy eschatologie, bytí v čase znamenalo radostné očekávání budoucnosti, respektive věčnosti (Assmann 2013: 271). Na rozdíl od tohoto času „obtěžkaného budoucností“ je moderní sekulární čas „prázdným časem“ a neměnnou veličinou, s níž nelze manipulovat. Ve starém režimu Bůh může do času zasáhnout a změnit jej - tato víra umožnila i snazší konceptuální přijetí průlomu věčnosti do běžného časového režimu.

Myšlenku průlomu posvátného do profánního času usnadňovala i zmíněná představa koexistence různých kulturních časů. Jednak umožňovala chápání věčnosti jako paralelně probíhajícího časového režimu, jednak vnášela do myšlení o čase prostorový aspekt. Tuto závislost času na prostoru vztahuje Aron J. Gurevič zejména k lidové kultuře a nazývá ji „spacializací“; můžeme ji však obecně aplikovat i na starý režim vnímání času. Podle Gureviče představuje lidová kultura čas pomocí prostorových modelů: „klade bok po boku minulé, přítomné a nadcházející;; pamět minulého není dlouhá a očekávání budoucího je v důsledku všeobecného ducha eschatologie krátké (Gurevič 1996: 285-286). Ostatně s podobným zdůrazněním př́tomnosti se setkáváme už ve Vyznáních sv. Augustina - minulost je př́tomnou upomínkou minulého, budoucnost př́ítomným očekáváním budoucího:

\section{„Chci zazpívati známou píseñ. Nežzačnu, vztahuje se mé očekávání na celou piseñ. Fakmile jsem začal, tolik utkvívá v mé pamèti, kolik jsem zpěvem takořka poslal v minulost, a celá má činnost může býti nazvána vzpomínkou s hledem k tomu, co jsem zazpíval, a očeká- váním s hledem k tomu, co mám zazpívati." (Augustin 1926: 413)}

Starý režim vnímání času tudíž můžeme definovat jako výrazně zaostřený na př́tomnost a vázaný na prostor. Čas se skládá z nekonečného množství paralelních př́tomností a - slovy Assmannové - je chápán jako čas k jednání, čas definovaný a zprostředkovaný činností (Assmann 2013: 33-34). Také snahy pochopit či přiblížit věčnost byly nejsnáze realizovány pomocí děje, bylo tudíž nutno vyprávět, narativizovat. Proto se tato studie bude věnovat různým způsobům narativní inscenace věčnosti. 


\title{
Zpěv ptáčka
}

Jako zakladatel křestanského myšlení o čase a věčnosti bývá právem jmenován sv. Augustin. V jeho Vyznáních lze také nalézt dvě základní konstanty lidského rozumění času: neoddělitelnou spjatost s prostorem a schopnost artikulovat jej pomocí vyprávění (Ricoeur 2000: 27, 30).

\begin{abstract}
„Festliže jest budoucí a minulý čas, chci věděti také, kde jest. Nemohu-li však toho dosud pochopiti, vím přece, že at'jsou kdekoliv, nejsou tam jako budoucí nebo minulé, nýbržjako prítomné; nebot'kdyby tam byly jako budoucí, dosud by tam nebyly; kdyby tam byly jako minulé, již by tam nebyly. At'jsou tedy kdekoliv a at'jsou črmkoliv, jsou jenom jako prítomné. Ovšem, mluví-li se o minulém díle pravdy, vybavují se z paměti ne věci samy, jež zanikly, nýbrž slova vzniklá z představ věcí," rozvažuje Augustin (Augustin 1926: 396-397).
\end{abstract}

Jeho otázka byla patrně z větší části podložena metaforickým chápáním prostoru, sepětí času a prostoru ale později rozvinula i bohatá filozofická tradice. Setkáme se s ním též v narativních zobrazeních věčnosti. A právě vyprávění, tedy „pamět" či „slova vzniklá z představ věcí“, je to, co může člověku pomoci při chápání času.

Středověké a raně novověké pokusy zobrazit trvání věčnosti spoléhaly právem na sílu narace, at' už to byla některá $\mathrm{z}$ výše uvedených metafor či rozsáhlejší exemplum. Subjektivní vnímání dlouhého nebo naopak krátkého času se díky naraci promítlo i do popisu věčnosti: pro zavržené v pekle byla věčnost nekonečně dlouhá, pro spasené v nebi se zdála krátká jako okamžik. Výše citované metafory o zrnech písku, slzách atp. ilustrují spíše první př́pad. Druhý, „optimistický“ př́stup k věčnosti dokládá řada exempel, z nichž ta základní zachycuje Thompsonův katalog motivů pod číslem D.2011 (Years/days seems moments). V českém prostředí se ujalo zvláště vyprávění o mnichovi, který se při rozjímání o věčnosti vydal za zpěvem ptáčka do hájku nedaleko kláštera. Podle svého zdání naslouchal ptačímu zpěvu krátký čas, ale když se vrátil zpět do kláštera, zjistil, že uplynulo několik set let.

Toto exemplum pochází snad původně ze Španělska (mnich Fortunatus), nejčastěji je ale spjato s cisterciáckým mnichem Felixem, respektive mnichem z Heisterbachu; jeho nejstarší doklad pochází ze 13. století, variantně už z konce 12. století v kázáních Maurice de Sully (Hammerich 1943: 425). Je ovšem známo také jako irská legenda o sv. Mochaoi, jako kastilská píseň ze sbírky mariánských zázraků, objevuje se i v ruské, srbské či islandské verzi (ATU 471A; Koch 1883: 42; Hammerich 1943: 425-427; Vašica 1995: 
282; Jaluška 2019: 229-231). V bohemikální literatuře je př́běh mnicha a ptáčka doložen poprvé v Klaretově sbírce exempel, tedy ve druhé polovině 14. století (Dvořák 1978: 16, 17, 108). Jako exemplum jej použil např́́klad Šimon Lomnický na počátku 17. století, v Křest'anském učení jej zveršoval Fridrich Bridel (1681), odkazovali na něj někteří kazatelé z 18. století (Vašica 1995: 51-52). V obecném povědomí žilo toto exemplum ještě po celé 19. století - setkáme se s ním např́iklad u Jana z Hvězdy, Adolfa Hejduka či v básni Josefa Horkého z roku 1898. V této době se však již stírala původní funkce exempla - středověké doklady kladou důraz na projev zázračné moci Boha (či Marie) a př́běh většinou okleštují na holý narativ, přičemž spoléhají na posluchačovu schopnost chápat a imaginativně rozvíjet symboly. Oproti tomu např́klad u Jana z Hvězdy (tedy Jana Jindřicha Marka) je katechetická funkce př́běhu potlačena, hlavní pozornost na sebe poutají romantické popisy starého kláštera a prrírody; romantická je také soustředěnost na postavu mnicha - vyvržence z času a na jeho niterné prožívání zmíněných událostí (Marek 1823: 108-112).

Ústředním tématem exempla $\mathrm{v}$ jeho středověké a raně novověké podobě je nesouměřitelnost lidského prožívání času s věčností. Využívá přitom nejen širokého symbolického potenciálu, který na sebe váže ptáček (pták jako Boží posel, chytání ptáka jako symbol poznání), ale také sepětí zpěvu s prožíváním času. Připomeňme známý úryvek z Augustinových Vyznání, v němž je trvání času vysvětlováno na naslouchání melodii; tento motiv je ale prŕtomen i v židovské nebo např́klad indické tradici (Koch 1883: 37). Na rozdíl od níže uvedených príběhů není toto exemplum o zpěvu vyprávěním o nebi, ale klade si pouze otázku vnímání času a odpovídá na ni čistě symbolicky. Motivicky jsou s ním spřízněna také další vyprávění s tématem „roky/dny jako okamžik“, ta se však vždy alespoň náznakem pokoušejí popsat, co jejich aktéŕi v nebi viděli; exemplum o mnichu a ptáčkovi je nejčistším způsobem narativního inscenování času. Věčnost je v něm dokonale neměnná, statická - jak ji popisuje Augustin - a také její prožívání odpovídá kultuře starého časového režimu. Aleida Assmannová mluví o změně, která do vnímání času začala pronikat už s puritánstvím v 17. století: vznikla snaha neztrácet čas, využít každý okamžik, naplánovat budoucnost (Assmann 2013: 25-26). Tento „ohraničený čas“ je dalece vzdálen od mnicha, jenž se při zpěvu ptáčka zapomněl na několik set let.

\section{Svatba}

Přibližně ve stejné době jako exemplum o mnichu a ptáčkovi vznikl tematicky př́ibuzný příběh o svatbě mladého šlechtice; v některých verzích bývá považován za syna italského vévody, jindy hraběte, knížete, či 
dokonce krále. Tento mládenec se na radu svých přátel oženil a na svatbu přizval starce, jehož potkal cestou v horách. Stařec mladého ženicha na oplátku pozval k sobě na slavné hody; mladík se po třech dnech vydal na cestu a starcův mezek jej dovezl až do nevýslovně krásného kraje (ráje), uprostřed nějž bylo město. Tam mládence uvítal stařec - archanděl Rafael (v některých variantách sám Bůh). Mladý ženich $\mathrm{v}$ této blaženosti strávil zdánlivě krátký čas, poté se - přes varování starce - vrátil domů ke své nevěstě. Doma však nalezl místo otcovského hradu klášter s neznámými mnichy a dozvěděl se, že od jeho odjezdu uplynulo více než tři sta let. Když príijal svátosti (variantně: okusil pokrmu), náhle zestárnul a zemřel.

Písemné doklady tohoto př́iběhu přinášejí různě variantní znění, jejichž četnost a vzájemné vztahy přesahují rozměry této studie. Také geneze základní látky je značně složitá. Na počátku snad stojí syrská legenda o sv. Alexiovi z 5. století a z ní vycházející život Macaria Římského ze 7. století - v obou se vyskytuje základní motiv ženicha, jenž po svatbě opustil svou nevěstu, v Macariově legendě navíc figuruje anděl Rafael jako průvodce (Hammerich 1943: 426). Ovšem základní podoba zápletky, především motiv vytržení z času, jsou doloženy až z počátku 13. století. Př́íběh o ženichovi v nebi lze stěží označit za exemplum, tedy krátké mravoučné vyprávění, zpravidla užité v rámci jiného textu (kázání) jako argument. V rukopise z počátku 13. století je představen jako zakladatelská legenda benediktinského kláštera v italských Alpách (Schwarzer 1882: 338); Šimon Lomnický jej zpracoval do podoby knížky lidového čtení (Voit 1988); dostal se také jako pohádka do ústní lidové slovesnosti např́klad ve Švýcarsku či Korutanech, ale i na Moravě (Reissenberger 1901: 301); od druhé poloviny 17. století, zvláště pak na přelomu 18. a 19. století, se objevuje jako česká kramářská píseň Poslyšte mile, co chci zpívati (poprvé roku 1666 v opavském tisku pod názvem Píseñ o jednom mládenci, na jehožto svatbě anjel Rafael byl). V ní také mladý ženich získává „mluvící jméno“ Theofil; ve většině zpracování této látky zůstává hlavní hrdina bezejmenný, pouze německá verze z 15. století mu dává jméno Loringus (Koch 1883: 41).

$\mathrm{S}$ ohledem na konfrontaci lidského času s věčností zde hraje důležitou úlohu motiv svatby. Svatba představovala vytržení z profánního času, průlom věčnosti (Eliade 1994: 129). Ne náhodou je prolomení věčnosti do lidského času spojeno se svatbou také $\mathrm{v}$ jiné kramářské písni. Píseň s incipitem Ach slávo, slávo nebeská vypráví o Terezii, dceři uherského komandanta, která se zaslíbila Bohu, ale otec jí vystrojil svatbu; když se zarmoucená procházela v zahradě, přidružil se k ní Kristus, daroval jí prsten a trhal s ní květiny. Poté ji pozval do své zahrady, v níž pobyla malou chvíli - když se však vrátila domů, zjistila, že uplynulo sto dvacet let. Podobně jako Theofil přijala Terezie svátosti, v okamžiku zestárla a zemřela. První dochovaný 
výtisk českého textu pochází až z roku 1735 (Píseň historická o jedné bohabojné dceři v Uhř́ch, městě Vardajnu zrozenê), vzorem mu mohla být německá verze, pocházející přibližně z téže doby (Koch 1883: 42; Reissenberger 1901; Vašica 1939: 283). V české i německé tradici se tato píseň šírila především v ústním lidovém podání, podobně jako píseň o Theofilovi se často zpívala na svatbách (Horák 1910; Holzapfel 2006: O 19).

Svatba či jiný svátek je branou mezi pozemským časem a věčností také v hojně rozširréené skupině exempel "přátelé v životě i ve smrti“. Dva přátelé si vzájemně slíbí, že se pozvou na svatbu; když jeden z nich zemře, druhý přijde $\mathrm{k}$ jeho hrobu s pozváním (v některých variantách zve opilec oběšence na posvícení). Mrtvý na oplátku pozve živého - když se však živý vrátí zpět ke své rodině, zjistí, že uplynuly stovky let. Toto exemplum se rozšriŕilo po celé Evropě, známe dokonce i jeho japonskou verzi. Motiv vytržení z času v něm není vždy bezvýhradně přítomen - příběh se potom stává pouze př́íkladem věrného přátelství (ATU 470; Petschel 1987; Tille 1918: 194-195). Nesouměřitelnost věčnosti a času je v těchto exemplech jen bočním motivem, znamením toho, že došlo k prolnutí přirozeného a nadpřirozeného světa.

Jak v př́běhu o Theofilově svatbě či v písni o dceři uherského komandanta, tak i v posledním zmíněném exemplu odpovídá popis věčnosti Augustinovu pojetí: věčnost je statická, neměnná, nedějová. Proto je také vylíčení nebe značně redukováno, často pomocí symbolických náznaků (např. uherská panna se prochází v „zahradě“). Cílem zde není podrobně popsat zásvětí a jeho obyvatele, ale vyprávět o odměně těch, kdo se zasvěcují Bohu (Terezie, Theofil), vyprávět o věrném prátelství či o nesouměřitelnosti lidského času s věčností. Tím se všechna zmíněná vyprávění liší od žánru zvaného visio.

\section{Visio}

Visio čili vidění je typickým žánrem raného středověku, třebaže se s texty tohoto druhu setkáváme i později. Dominuje v něm popis nebe, pekla či očistce, okolnosti vstupu do zásvětí tvoří pouze podružný rámec celého vyprávění. Podobně jako ve výše zmíněných textech je vstup do jiného světa umožněn díky průvodci - nejčastěji jím bývá anděl. V některých viděních probíhá děj v zásvětí v jiném časovém režimu než děj pozemský, ale ve srovnání s exemply o svatbě či zpěvu ptáčka, kde během okamžiku uplynulo několik desítek či stovek let, je tato nesouměrnost časů řádově menší. Například „bezelstný mladíček Orm“ se domníval, že jeho vidění netrvalo více než hodinu, přitom však ležel třináct dní jako mrtev; Thurkill strávil v zásvětí podle svého zdání sotva jeden den, ve skutečnosti to ale 
byly dva dny a dvě noci (Engelbrechtová - Moravová - Nodl 2011: 100, 204). Vytržení z času zde sice signalizuje protnutí pozemského a posvátného času, je nicméně mnohem kratší a týká se pouze vizionářovy duše - jeho tělo zůstává ve stavu podobném spánku, ve zdánlivé smrti. Proto také po svém procitnutí z vize nezestárne a nezemře; někdy je živ krátký čas, obvykle ale prožije ještě mnoho let, aby mohl svědčit o tom, co viděl. Snad právě z tohoto důvodu netrvá vytržení z času nikdy př́liš dlouho - visio je poselstvím či varováním pro vizionářovy současníky.

Výše zmíněná exempla o ptáčkovi, Theofilovi atp. se týkala pouze nebe, ve viděních se však objevuje i peklo a očistec. Trvání věčnosti zde tudíž není chápáno bezvýhradně pozitivně. Doba strávená v pekle či očistci se také zdála neúměrně delší. Od Augustinova pojetí nehybné a neměnné věčnosti se zásvětní čas visií liší ve dvou zásadních aspektech: je dynamický, bohatý na události, měřitelný, střídají se v něm pravidelné rytmy stejně jako v čase pozemském. Ti, jimž se vidění dostalo, zpravidla procházejí složitě strukturovaným nebem či peklem, potkávají se s vyvolenými či se zatracenci, dozvídají se o jejich osudech, poctách, mukách atp. Do jejich vyprávění často vstupují konkrétní historické osobnosti a celkově vzato je věčnost, jak ji představují visia, mnohem bližší lidskému světu než exempla o ptáčkovi a o svatbě; také se více podobá lidskému času, který je třeba vyprávět, zprostředkovat skrze naraci (Ricoeur 2000: 88). Uplývá a dá se měřit - např́klad nebeští ptáci odměřují svým zpěvem kanonické hodinky, v pekle jsou zatracenci každou neděli zproštěni muk (Gurevič 1996: 280, 281). V tomto časovém režimu lze stěží inscenovat výraznější vytržení z času; proto je větší disproporce mezi posvátným a profánním časem výjimkou. Vyskytuje se především u textů, jež se k visiím řadí jen okrajově: např́iklad ve vyprávění o plavbě k ostrovům pozemského ráje (Gurevič 1996: 282).

\section{Sekundární ráje a pekla}

Plynutí času na bájných rajských ostrovech patří spíše k vyprávěním o hrdinovi, který pronikne do kouzelné ř́šse, obyčejným smrtelníkům nepř́stupné; často také uplyne mnoho let, ačkoliv hrdinovi se to zdá jako okamžik. Tento motiv je rozšířen v pohádkách a pověstech takřka ve všech kulturách, a to nejen evropských; připomeňme alespoň různé germánské pověsti o království trpaslíků, v němž smrtelníci strávili sto i více let (Koch 1883: 30-32). Nejen v českém prostředí se v nesčetných variantách vyskytuje pověst o pokladu skrytém v hoře - př́stup k němu je otevřen pouze na Velký pátek (př́p. Květnou neděli). Náhodou se k němu dostane matka s dítětem a nabírání zlata ji zaměstná natolik, že si na své dítě vzpomene, až když se skála zavře a ono v ní zůstane uvězněné. Po roce je tam však najde živé 
a zdravé. Nejznámějším zpracováním této pověsti je asi Erbenův Poklad, zachycuje ji ale již česká legenda o sv. Klimentu ze 14. století, podle níž se moře rozestupuje každý rok na výročí Klimentovy smrti, aby odhalilo podmořský chrám. Podobná pověst se v Čechách váže k nejrůznějším místům, např́klad k Landeku, Koštálovu, Ronovu atd. Různé varianty vyprávějí též o pasačce, mladíkovi, ševci či dvou chlapcích uvězněných ve skále. Ne vždy se také jednalo o poklad - např́klad u Jimramova tančila děvečka Hana s rytíri ve skále sto let.

Místo, kam se hrdinové těchto př́iběhů dostanou, je vždy vytrženo z běžného lidského prostoru, je určitým způsobem posvátné, respektive nezemsky př́jemné a dokonalé, či naopak připomínající pekelný trest (potrestání lakomství, hřríného sklonu k tancování a marnivosti). Nejzřetelněji se ideální říše jeví v pohádkách, at' už lidových či autorsky zpracovaných. Tak např́klad představuje království skřítků Božena Němcová v pohádce Jak Jaromil ke štěstí prì̌el (Jaromil dokonce na několika místech výslovně ř́ká, že je tu krásně jako v ráji nebo jako v nebi). Zde ovšem vytržení z času není absolutní - Jaromilovi se sice jeví čas strávený mezi skř́tky jako chvíle, třebaže u nich byl deset let, ale do lidského světa se vrací skutečně starší; místo chlapce je z něj mládenec. Podobně je tomu i v Tieckových Skř́tcích (Die Elfen), z nichž Němcová při psaní volně čerpala.

Ve všech př́padech se již nejedná přímo o věčnost, ale o rozdílné časové režimy obyčejného a kouzelného světa. Spíše než o „vytržení z času“ vyprávějí tyto prameny o přechodu do oblasti, v níž čas plyne jinak. Nesouměřitelné plynutí času je pouze jednou z charakteristik, která zdůrazňuje nadpřirozenou podstatu zobrazovaného světa a odděluje jej od běžného režimu profánního fungování. Toto oddělení je zpravidla znázorněno závažnou překážkou: horou či skálou, mořem atp., a to překážkou zdánlivě nepřekonatelnou. Hrdinu přes ni může převést průvodce (pták u Jaromila, pes ve Skř́tcích), často je zde ale klíčový časový moment. Skály se otevírají na Velký pátek či Květnou neděli, moře v den Klimentova úmrtí: v tyto dny je profánní čas nahrazen posvátným, který umožňuje průlom do nadpřirozeného světa.

\section{Spánek}

Ve zmiňované legendě o sv. Klimentu usne dítě v podmořském chrámu, a když se pro ně matka za rok vrátí, nalezne je stále spící. Vytržení z času znázorněné nepřirozeně dlouhým spánkem známe už např́klad z antického mýtu o Epemenidově spánku či z pověsti o sardinských spáčích, kterou zmiňuje ve Fyzice Aristotelés (Aristotelés 1996: 121), nebo z Talmudu na přelomu 4. a 5. století, kde je zaznamenána pověst o rabi Oniášovi, také v 18. súře Ko- 
ránu se mluví o mladících spících v jeskyni, jim se podobají i tzv. Sedmispáči v křestanské legendě ze 4 . století. Dlouhý spánek se stal později oblíbenou literární zápletkou, připomeňme třeba Irvingovu povídku Rip Van Winkle (1819) či bezpočetné hibernace v literatuře science-fiction (srov. též ATU 766).

Moderní literaturu a staré mýty propojuje rozsáhlá a spletitá geneze této látky, která je často vázaná na folklorní tradici. Motiv dlouhého spánku hojně rezonoval v místních pověstech o vojsku, které spí v hoře, připravené vyrazit na pomoc do poslední bitvy: tak tomu je např́klad s českým Blaníkem, Boubínem či Oškobrhem, polskou Babí horou nebo německým Kyffhausenem. Důležitou úlohu hraje tento motiv i v pohádkách: spánek, či př́mo smrtelný spánek, je v nich spojen především s princeznami, at' už je to Sněhurka nebo německá Včelí králoona (Bienenkönigin) či italská Schiavottella. Nelze samozřejmě opominout Šípkovou Růženku, v níž tvoří stoletý spánek hlavní zápletku. Dnešní podoba této pohádky vychází z díla bratř́ Grimmů, její verzi s méně idylickým pokračováním zveřejnil už Charles Perrault v Pohádkách matky husy (1697). Její původ lze hledat již kolem roku 1330 v př́běhu o Troïlovi a Zellandine ve francouzském románu Perceforest. Způsob, jakým probíhá vytržení z času u Růženky a u Zelladine, je však diametrálně odlišný: Růženka spí sto let a probudí se stejně mladá, jako usnula - nezměněná, jako by prospala jedinou noc. Zelladine spí pouhých devět měsíců, na jejichž počátku je početí a na konci porod dítěte. Není tudíž vytržena z času jako Růženka a celé její království, avšak podléhá jeho běhu stejně jako ostatní smrtelníci.

I v příběhu Růženky a dalších „spáču“ ale chybí zásadní aspekt, který provázel vytržení z času popsané v předchozích kapitolách. Jejich tělo sice nepodléhá změnám uplývajícího času - bud' brzy po probuzení rychle zestárnou a zemřou (Oniáš, Sedmispáči), nebo spíše žijí ještě dlouhá léta - nicméně jejich duše skutečně spí. Zůstávají stále součástí svého světa, ačkoli jej nevnímají. Zcela zde chybí motiv přechodu do jiného světa (nebe atp.) s jiným časovým režimem. Aristotelés píše o sardinských spáčích, že „pro nepřítomnost vnímání vypouštějí čas“ (Aristotelés 1996: 121), tak je tomu i v ostatních príbězích o dlouhém spánku. Spánek je zde analogií smrti. Jiná vyprávění mají protagonisty v bdělém stavu, podmínkou jejich vytržení z času je zároveň vytržení z prostoru, musí někam odejít. Výjimku tvoří pouze visia, v nichž tělo zůstává na tomto světě, duše však odchází do zásvětí. Ve visiích a dalších príbězích je tedy podstatná aktivita a bdělost duše, činnost a změna těla není podmínkou (v př́íběhu o Zelladine je duše spící a tělo podléhá okolnímu času). V exemplech o rychlém ubíhání času je naopak často př́tomen motiv krátkého, či dokonce žádného spánku: podle Bridela mnich naslouchající ptáčkovi „snem nikdy přemožen nebyl“ (Bridel 1994: 261). 


\section{Závěr}

Zpěv ptáčka, svatba, dlouhý spánek - všechny tyto základní typy příběhů obsahují více či méně významný motiv vytržení z času, střetnutí časovosti $\mathrm{s}$ věčností. Jejich typologie, kterou jsem se zde pokusila nastínit, není nijak ostrá a jistě nezahrnuje zdaleka všechny př́pady. Pořadí, v jakém jsem je uvedla, je dáno sestupnou tendencí, vzdalováním se od čistého prototypu časového exempla až $\mathrm{k}$ jeho nejméně jasným variantám, v nichž vytržení z času hraje obvykle jen podružnou roli a v nichž nese ,jiný čas“ stále rysy lidského času, nikoli věčnosti.

Exemplum o mnichovi a ptáčkovi má primárně za cíl ukázat nesouměřitelnost času a věčnosti: vyhýbá se jakémukoli popisu zásvětí, ba ani nemluví o tom, že by mnich byl v nebi; čtenář či posluchač je zde odkázán na řeč symbolů a náznaků. Všechny ostatní typy př́iběhů se do jisté míry snaží vyplnit mezeru oněch let, jež hrdina tráví v nebi, a nabízejí alespoň minimální popis toho, co tam dělal. Př́íb̌h o zpěvu ptáčka je však soustředěn čistě na čas. Podobně je tomu i u následující skupiny př́iběhů o Theofilově svatbě, uherské panně či věrném prátelství. V nich se už sice objevuje rozvedení epizody o hrdinově pobytu v nebi, ale zjevně to není těžištěm celého prŕběhu - tím je opět vytržení z času. Popis nebe je založen převážně na symbolických prototypech vycházejících z knihy Zjevení či staré křestianské tradice (zahrada, opevněné město atp.), a především na reprodukci rozhovorů, které tam hrdina vedl s Bohem či vyvolenými. Čas strávený v nebi je augustinovsky statický, nedějový.

Čas visií je stále ještě časem posvátným, svými vlastnosti se však již připodobňuje běžnému lidskému času: dá se měřit a je naplněn dějem, a to mnohdy velmi nesymbolickým a konkrétním, odpoutaným od biblických archetypů. Cílem vidění bylo popsat zásvětní svět, jinak plynoucí čas mohl být (a často ani nebyl) jen jednou z mnoha charakteristik ,jinakosti“. Podobně je tomu i u pohádek a pověstí - jiné plynutí času ukazuje na přechod do jiného světa. Vypravěč se však zaobírá popisem tohoto světa a dějem, který se v něm odehrává, nikoli časem jako takovým. Oproti visiím není tento jiný svět jednoznačně nebem, peklem či očistcem, třebaže mnohé prvky, jimiž je popisován, vycházejí z náboženských archetypů. Konečně př́běhy založené na motivu dlouhého spánku zcela postrádají onen přechod do jiného světa; jsou jen zázračným zastavením času, kdy tělo (většinou) nepodléhá změnám, duch však - na rozdíl od všech předešlých př́kladů - nic nevnímá. Toto osobní zastavení času pak již tvoří plynulý přechod $\mathrm{k}$ dalším př́běhům o jiném pozastavení času či o moci nad časem a smrtí, at' už je to pohádka o kmotřičce smrti či o kováři a zavřené smrti (ATU 330, ATU 332). 
Předestřená škála př́běhů je zajisté značně nedokonalá a různorodá, přesto z ní však můžeme vyabstrahovat základní atributy, jež provázejí inscenování věčnosti či obecně jiného času v narativních textech starého časového režimu. $V$ prvé řadě je to úzké sepětí času a prostoru - přechod do jiného časového režimu (věčnosti) je podmíněn změnou v prostoru. Theofil odjíždí na mezku do hor, mnich odchází za hlasem ptáčka do hájku, Terezie jde s Kristem do zahrady, matka s dítětem do nitra hory, Jaromil neznámým údolím a skalní štěrbinou do krásné zahrady atd. Vstoupení do posvátného času se tudíž děje prostřednictvím cesty v prostoru. Mnohdy je tento čas také oddělen prostorovou překážkou: horami, skálou, mořem, trním... Tato překážka znázorňuje nepřekročitelnost: není branou, která implikuje možnost vstoupit, ale masou živlů, kterou nelze za obyčejných okolností překonat. Přes tuto překážku může hrdinu převést průvodce, jenž náleží jinému světu: anděl, pták (jenž bývá často alegoricky interpretován také jako anděl, Boží posel), sám Kristus, zemřelý atp. Tento průvodce může hrdinu doprovázet i po zásvětí, často se však jeho úloha omezuje jen na převedení přes hranice.

Možnost vstupu do jiného časového režimu neskýtá ani tak prostor, jako spíše okamžik, kdy se stýká čas profánní s časem posvátným - průlom věčnosti do toku světského času. Tento průlom se může vázat na univerzální božský čas: na cyklické svátky, které strukturují plynutí lidského času a jejichž prostřednictvím se člověk symbolicky znovu a znovu účastní zásadních událostí, jako je stvoření světa či vykoupení lidstva. Je jimi vyvazován z toku lineárního, či spíše profánního času - tak je tomu např́klad při otevírání pokladů na Velký pátek či Květnou neděli, také moře se rozestupuje právě na výročí umučení sv. Klimenta. Cykličnost těchto svátků není v křestanském světě v protikladu k lineárnímu vnímání času, nebot' Bůh může do dějin vstupovat kdykoli, nejen na jejich počátku či v průběhu cyklického připomínání stvoření. Okamžiky, v nichž je průlom mezi posvátným a profánním časem snazší, jsou umocněny různými rituály - at' už jsou to rituály vázané na zmíněné svátky, nebo rituály přechodové, např́klad svatba (Eliade 1994: 129): připomeňme mládence Theofila a uherskou pannu Terezii či pozvání na svatbu v exemplu o věrném přátelství.

Také v pohádce o Růžence je proces vytržení z času vázán na zásadní okamžik a rituály s ním spjaté (narozeniny, dosažení dospělosti), přestože se již nejedná o průlom do posvátného času a charakter této časové jinakosti se zřetelně liší od výše uvedených př́íkladů: Theofil, vizionáři a další hrdinové se dostávají do nadpřirozeného světa, prostřednictvím „spáčüu se naopak nadpřirozený svět prolamuje do reálného. Růženku nepřenáší její spánek do režimu věčnosti, pouze ji zachovává pro budoucnost, stejně jako hibernace hrdinů v současné sci-fi literatuře či filmu. Rozdíl je však v samotné podstatě 
spánku: u Růženky, rabbiho Oniáše či Sedmispáčů za ním stojí nadpřirozená moc, at' už je to Bůh či třeba zlá sudička. Ve světě sci-fi je hibernace zcela běžná, nevymyká se z jeho zákonitostí, hrdina upadá do kryospánku většinou z vlastní vůle a za pomoci běžných „vědeckých“ prostředků. Att už je to hrdina Avatara (2009), pro nějž je hibernace způsobem, jak překonat šest let dlouhou cestu ze Země na Alfu Centauri; at' už jsou to dílčí epizody Hvězdné brány (1997-2007), či at jsou to opakované hibernace Ripleyové, přední hrdinky kultovního Vetřelce (1979-2017). Pozoruhodné je, že např́klad v narativu Vetřelce plní hibernace podobnou funkci jako u Růženky: Ripleyová usíná, aby nemusela zemřít (a příběh aby mohl pokračovat). Probouzí se pak v budoucí, vhodnější době. Některé př́iběhy zkrátka nikdy nezmizí.

Pro vyprávění sledovaná v této studii znamená vytržení z času vkročení do jiného časového režimu, nejčastěji do věčnosti; v kultuře moderní doby je věčnost nahrazena budoucností. Moderní cesty do minulosti a budoucnosti nemění nic na samotném chápání času, jeho kvalita je stále totožná. Staré pověsti a exempla oproti tomu ukazují čas a věčnost jako dvě diametrálně odlišné podstaty. Věčnost, či obecně jiný časový režim, v nich nezná minulost a budoucnost - je neustálou prítomností. S tím souvisí také eschatologie, v kultuře starého režimu neustále, latentně přítomná. Moderní společnost, at už $\mathrm{k}$ těmto pojmům přistupuje z náboženského hlediska či nikoli, spojuje eschatologii s budoucností; ve společnosti starého režimu je napojena na př́tomnost. Není tedy divu, že inscenace věčnosti, s níž se setkáváme u mnicha $\mathrm{z}$ Heisterbachu či ve visiích, používá odlišných prvků než moderní kultura: časové režimy, které popisují, jsou totiž zcela odlišné.

Zář́ 2020

\section{Prameny}

Aristotelés. 1996. Fyzika. Přeložil Antonín Kříž. Praha: Petr Rezek.

Augustin. 1926. Svatého otce a učitele církve Aurelia Augustina Vyznání. Pře-

ložil Mikuláš Levý. Praha: Ladislav Kuncír.

Bridel, Fridrich. 1994. Básnické dílo. Ed. Milan Kopecký. Praha: Torst Societas.

Engelbrechtová, Jana - Moravová, Magdalena - Nodl, Martin et al.

(eds.). 2011. Ráj, peklo a očistec ve středověkých vidèních. Praha: Argo. Jaluška, Matouš (přel. a ed.). 2019. Sto písní o Marii. Toledský kodex Cantigas de Santa Maria krále Alfonse X. Učeného. Praha: Univerzita Karlova - Filozofická fakulta.

Malobický, Jan. 1681. Dům věčnosti. Praha: Jezuitská tiskárna (Knihopis č. K05159). 
Manni, Giovanni Battista. 1676. Věnec věčnosti. Přeložil Jakub F. A. Vrba. Praha: D. Michálek (Knihopis č. K05174).

Marek, Jan Jindřich. 1823. Básně. Praha: Josefa Fetterlová.

Píseň historická o jedné bohabojné dceři v Uhř́ch, mëstě Vardajnu zrozené. 1735.

Opava: [Jan Václav Schindler ml.?] (MZK, sign. VK-0000.643, přív. 6). Píseñ o jednom mládenci, na jehožto svatbě anjel Rafael byl. 1666. Olomouc:

Vít Jindřich Ettel (MZK, sign. VK-0000.543, př́iv. 10).

Šteyer, Matěj Václav (ed.). 1683. Kancionál český. Praha: J. Černoch (Knihopis č. K15935).

\section{Literatura}

Assmann, Aleida. 2013. Ist die Zeit aus den Fugen? Aufstieg und Fall des Zeitregimes der Moderne. München: Hanser.

Dvořák, Karel. 1978. Soupis staročeských exempel. Praha: Univerzita Karlova.

Eliade, Mircea. 1994. Posvátné a profánní. Přeložil Filip Karfík. Praha: Česká křestanská akademie.

Gurevič, Aron. 1996. Nebe, peklo, svět. Cesty k lidové kultuře středověku. Přeložil Jaroslav Kolár. Jinočany: H \& H.

Hammerich, Louis Leonor. 1943. Mönch Felix. In: Stammler, Wolfgang - Langosch, Karl (eds.): Die deutsche Literatur des Mittelalters. Verfasserlexikon. Band III. Berlin: Walter de Gruyter: 425-427.

Holzapfel, Otto. 2006. Liedverzeichnis. Hildesheim: Olms.

Horák, Jiř́i. 1910. Píseň o dceři uherského kommandanta. Národopisný věstník českoslovanský 5: 50-53.

Koch, John. 1883. Die Siebenschläferlegende. Dresden: C. Reissner.

Koselleck, Reinhart. 1989. Vergangene Zukunft: zur Semantik geschichtlicher Zeiten. Berlin: Suhrkamp.

Petschel, Günter. 1987. Freunde in Leben und Tod. In: Ranke, Kurt (ed.): Enzyklopädie des Märchens. Band 5 Fortuna - Gott ist auferstanden. Berlin: De Gruyter: 282-287.

Reissenberger, Karl. 1901. Zu dem Volksliede von der Tochter des Kommandanten zu Grosswardein. Zeitschrift des Vereins für Volkskunde 11: 298-304.

Ricoeur, Paul. 2000. Čas a vyprávění. I. Zápletka a historické ryprávění. Přeložili Miroslav Petříček jr. - Věra Dvořáková. Praha: OIKOYMENH.

Schwarzer, Joseph. 1882. Visionslegende. Zeitschrift für deutsche Philologie 14: $338-351$.

Thompson, Stith. 1955-1958. Motif-Index of Folk-Literature. Indiana: Bloomington. 
Tille, Václav. 1918. Polívkovy studie ze srovnávací literatury. In: Horák, Jiří (ed.): Sborník prací věnovaných prof. Dr. F. Polívkovi k šedesátým narozeninám Společností Národopisného musea českoslovanského v Praze. Praha: Společnost Národopisného musea českoslovanského: 1-216.

Uther, Hans-Jörg. 2004. The types of international folktales. Helsinki: Suomalainen Tiedeakademia.

Vašica, Josef. 1995. České literární baroko: př́spězky k jeho studiu. Brno: Atlantis.

Vašica, Josef. 1939. Několik poznámek k baroknímu písemnictví. Řád 5: 281-289.

Voit, Petr. 1988. Kronika o mladém vejvodovi od Šimona Lomnického z Budče. Cesta od středověké legendy o zázracích k novodobé knížce lidového čtení, jarmareční písni a pohádce. Listy filologické 111: 110-119.

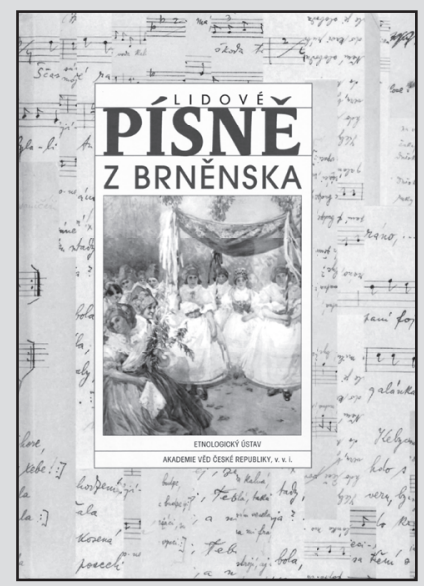

Kritická edice lidových písní z Brna a okolí vybraných z písňových fondů brněnského pracoviště Etnologického ústavu AV ČR. Součástí edice je studie o lidových písních z Brněnska, srovnávací komentáře a rejstř́ky sběratelů, lokalit a zpěváků.

Cena 100 Kč

ISBN 978-80-88021-26-5

\section{Marta Toncrová \\ Lidové písně z Brněnska \\ Vydal Etnologický ústav AV ČR, v. v. i. Brno 2020. 558 stran.}

